\title{
Supporting Information: Manipulating the Charge Transfer Absorption for Narrowband Light Detection in the Near-Infrared
}

Christina Kaiser, ${ }^{\dagger}$ Karl Sebastian Schellhammer, $§$ Johannes Benduhn, ${ }^{\ddagger}$ Bernhard Siegmund, II Manuel Tropiano, ‡ Jonas Kublitski, $¥$ Donato Spoltore, ${ }^{\ddagger}$ Michel Panhans, ${ }^{\S}$ Olaf Zeika, ${ }^{\ddagger}$ Frank Ortmann, ${ }^{\S}$ Paul Meredith, ${ }^{\dagger}$ Ardalan Armin, ${ }^{\dagger}$ Koen Vandewal $^{\perp}$

† Swansea University, Singleton Park SA2 8PP, Swansea, Wales, U.K.

‡ Dresden Integrated Center for Applied Physics and Photonic Materials (IAPP) and Institute for Applied Physics, Technische Universität Dresden, Nöthnitzer Straße 61, 01187 Dresden, Germany $\S$ Center for Advancing Electronics Dresden, Technische Universität Dresden, 01062 Dresden, Germany

\| Current address: Heliatek GmbH, Treidlerstraße 3, 01139 Dresden, Germany

${ }^{\perp}$ Instituut voor Materiaalonderzoek (IMO), Hasselt University, Wetenschapspark 1, BE-3590, Diepenbeek, Belgium

\section{$\underline{\text { Table of Contents }}$}

Cyclic Voltammetry: Figure S1-S2

Density Functional Theory Simulations: Equations (1)-(7), Table S1, Figure S3-S4

Device Architecture: Table S2

EQE under applied bias: Figure S5

IQE under applied bias: Figure $\mathbf{S 6}$

Internal Quantum Efficiency: Figure S7

Photodetector EQE Linewidth: Figure S8

Noise Characterization: Figure $\mathbf{S 9}$

Synthesis: Scheme S1 and Synthetic Protocols 
Cyclic Voltammetry
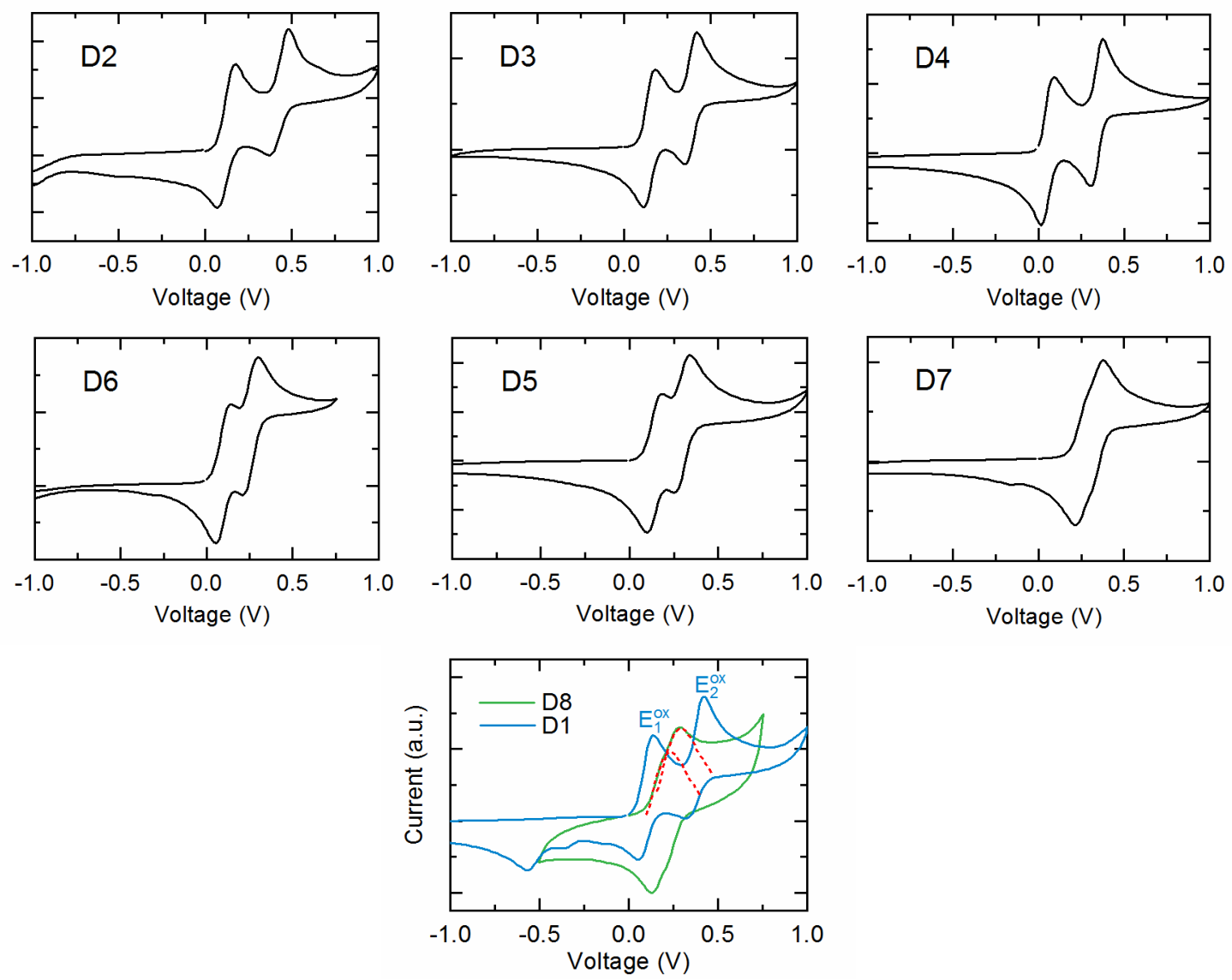

Figure S1. Cyclic voltammograms for D1 - D8 recorded in N,N-dimethylformamide. Donor molecules are characterised by either a pyranylidene or a thiopyranylidene core, which leads to a reversible double oxidation as exemplary demonstrated for D1 and D8. Depending on the substitution, the potential difference between the first and second oxidation potential $\left(\mathrm{E}_{1}^{\mathrm{ox}}\right.$ and $\left.\mathrm{E}_{2}^{\mathrm{ox}}\right)$ can vary.

a

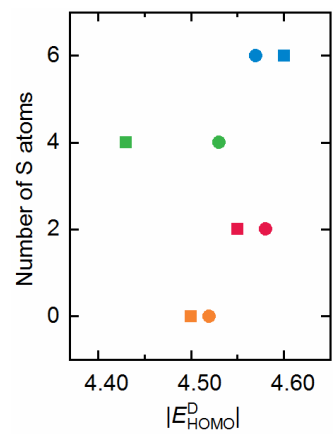

b

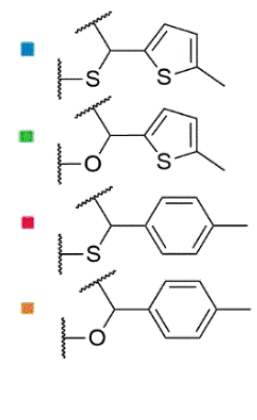

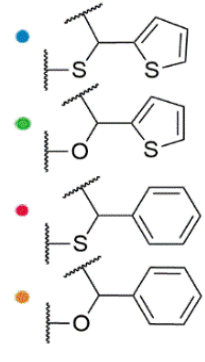

Figure S2. (a) The absolute HOMO energy level $\left|E_{\text {Hомо }}^{\mathrm{D}}\right|$ of the donor molecules estimated from the first oxidation potential $\left|\mathrm{E}_{\mathrm{OX}}^{1}\right|$ recorded in a cyclic voltammetry experiment (see Figure $\mathrm{S} 1$ ). $\mathrm{E}_{\mathrm{HOMO}}^{\mathrm{D}}$ in $\mathrm{eV}$ is obtained through internal referencing to the $\mathrm{Fc} / \mathrm{Fc}^{+}$redox couple according to $\mathrm{E}_{\mathrm{HOMO}}^{\mathrm{D}}=\left(\mathrm{EFc}_{\mathrm{Fc}+}-\mathrm{E}_{1}^{\mathrm{ox}}\right)+4.8 \mathrm{eV}$. (b) Characteristic molecular features of the donor molecules, where squares represent methylated donors and circles represent nonmethylated donors. 


\section{Density Functional Theory Simulations}

Gas phase values for vertical ionization potential $\mathrm{IP}_{0}$ and electron affinity $\mathrm{EA}_{0}$ of the neutral molecule as well as the ionization potential $\mathrm{IP}_{+}$of the cation are determined using

$I P_{+}=E_{++}\left(q_{+}\right)-E_{+}\left(q_{+}\right)$,

$\mathrm{IP}_{0}=\mathrm{E}_{+}\left(\mathrm{q}_{0}\right)-\mathrm{E}_{0}\left(\mathrm{q}_{0}\right)$,

$\mathrm{EA}_{0}=\mathrm{E}_{0}\left(\mathrm{q}_{0}\right)-\mathrm{E}_{-}\left(\mathrm{q}_{0}\right)$

with $\mathrm{q}_{\mathrm{i}}$ and $\mathrm{E}_{\mathrm{i}}$ the relaxed geometry and the ground-state energy for differently charged states, respectively. Molecular relaxation is characterized by the internal reorganization energies $\Lambda_{\mathrm{Di}}$, which is obtained using the potential energy surface method.[1] Polarization corrections can be calculated by assuming spherically shaped molecules with an ionic radius $r_{i}$ of the respectively charged species extracted from DFT calculations (ref. [2]-[4])

$\mathrm{P}_{\mathrm{i}}=\frac{\mathrm{q}^{2} \mathrm{e}^{2}}{8 \pi \varepsilon_{0} \mathrm{r}_{\mathrm{i}}}\left(\frac{1}{\varepsilon_{\text {rel }}}-1\right)<0$,

with $\varepsilon_{\text {rel }}=37.219$ for $\mathrm{N}, \mathrm{N}$-dimethylformamide and $\mathrm{q}^{2}=1$ for all charged states. With these considerations, the CV energy levels are given as

$$
\begin{aligned}
& \varepsilon_{\mathrm{OX} 2}=-\mathrm{IP}_{+}^{\prime}=-\left(\mathrm{IP}_{+}+3 \mathrm{P}_{+}-\frac{\Lambda_{\mathrm{D}++}}{2}\right), \\
& \varepsilon_{\mathrm{HOMO}}=-\mathrm{IP}_{0}^{\prime}=-\left(\mathrm{IP}_{0}+\mathrm{P}_{0}-\frac{\Lambda_{\mathrm{D}+}}{2}\right), \\
& \varepsilon_{\mathrm{LUMO}}=-\mathrm{EA}_{0}^{\prime}=-\left(\mathrm{EA}_{0}-\mathrm{P}_{0}+\frac{\Lambda_{\mathrm{D}-}}{2}\right) .
\end{aligned}
$$




\begin{tabular}{|c|c|c|c|c|c|}
\hline Molecule & $\begin{array}{l}\text { Gas phase } \\
\text { energies } \\
{[\mathrm{eV}]}\end{array}$ & $\begin{array}{l}\text { Reorganization } \\
\text { energy } \\
{[\mathrm{meV}]}\end{array}$ & $\begin{array}{l}\text { Polarization } \\
\text { energy } \\
{[\mathrm{eV}]}\end{array}$ & $\begin{array}{l}\text { Simulated CV } \\
\text { energies } \\
{[\mathrm{eV}]}\end{array}$ & $\begin{array}{l}\text { Experimental } \\
\mathrm{CV} \text { energies } \\
{[\mathrm{eV}]}\end{array}$ \\
\hline D1 & $\begin{array}{l}I P_{+}=9.14 \\
I P_{0}=5.76 \\
E A_{0}=0.66\end{array}$ & $\begin{array}{l}\Lambda_{++}=630 \\
\Lambda_{+}=290 \\
\Lambda_{-}=322\end{array}$ & $\begin{array}{l}P_{+}=1.37 \\
P_{0}=1.35 \\
P_{0}=1.35\end{array}$ & $\begin{array}{l}\varepsilon_{\mathrm{OX} 2}=4.72 \\
\varepsilon_{\mathrm{HOMO}}=4.27 \\
\varepsilon_{\text {LUMO }}=2.17\end{array}$ & $\begin{array}{l}\varepsilon_{\mathrm{OX} 2}=-4.80 \\
\varepsilon_{\mathrm{HOMO}}=-4.52 \\
\varepsilon_{\text {LUMO }}=--\end{array}$ \\
\hline D2 & $\begin{array}{l}I P_{+}=8.82 \\
I P_{0}=5.57 \\
E A_{0}=0.55\end{array}$ & $\begin{array}{l}\Lambda_{++}=625 \\
\Lambda_{+}=293 \\
\Lambda_{-}=304\end{array}$ & $\begin{array}{l}P_{+}=1.26 \\
P_{0}=1.26 \\
P_{0}=1.26\end{array}$ & $\begin{array}{l}\varepsilon_{\mathrm{OX} 2}=4.72 \\
\varepsilon_{\mathrm{HOMO}}=4.16 \\
\varepsilon_{\text {LUMO }}=1.96\end{array}$ & $\begin{array}{l}\varepsilon_{\text {OX2 }}=-4.79 \\
\varepsilon_{\text {HOMO }}=-4.50 \\
\varepsilon_{\text {LUMO }}=--\end{array}$ \\
\hline D3 & $\begin{array}{l}I P_{+}=8.97 \\
I P_{0}=5.77 \\
E A_{0}=0.91\end{array}$ & $\begin{array}{l}\Lambda_{++}=550 \\
\Lambda_{+}=286 \\
\Lambda_{-}=206\end{array}$ & $\begin{array}{l}P_{+}=1.34 \\
P_{0}=1.37 \\
P_{0}=1.37\end{array}$ & $\begin{array}{l}\varepsilon_{\mathrm{OX} 2}=4.66 \\
\varepsilon_{\mathrm{HOMO}}=4.26 \\
\varepsilon_{\text {LUMO }}=2.38\end{array}$ & $\begin{array}{l}\varepsilon_{\mathrm{OX} 2}=-4.77 \\
\varepsilon_{\mathrm{HOMO}}=-4.53 \\
\varepsilon_{\text {LUMO }}=-2.58\end{array}$ \\
\hline D4 & $\begin{array}{l}I P_{+}=8.57 \\
I P_{0}=5.53 \\
E A_{0}=0.78\end{array}$ & $\begin{array}{l}\Lambda_{++}=532 \\
\Lambda_{+}=303 \\
\Lambda_{-}=196\end{array}$ & $\begin{array}{l}P_{+}=1.29 \\
P_{0}=1.29 \\
P_{0}=1.29\end{array}$ & $\begin{array}{l}\varepsilon_{\mathrm{OX} 2}=4.44 \\
\varepsilon_{\mathrm{HOMO}}=4.09 \\
\varepsilon_{\text {LUMO }}=2.16\end{array}$ & $\begin{array}{l}\varepsilon_{\mathrm{OX} 2}=-4.73 \\
\varepsilon_{\mathrm{HOMO}}=-4.43 \\
\varepsilon_{\text {LUMO }}=-2.49\end{array}$ \\
\hline D5 & $\begin{array}{l}I P_{+}=9.05 \\
I P_{0}=5.84 \\
E A_{0}=0.91\end{array}$ & $\begin{array}{l}\Lambda_{++}=525 \\
\Lambda_{+}=286 \\
\Lambda_{-}=462\end{array}$ & $\begin{array}{l}P_{+}=1.33 \\
P_{0}=1.30 \\
P_{0}=1.30\end{array}$ & $\begin{array}{l}\varepsilon_{\mathrm{OX} 2}=4,80 \\
\varepsilon_{\mathrm{HOMO}}=4.41 \\
\varepsilon_{\text {LUMO }}=2.49\end{array}$ & $\begin{array}{l}\varepsilon_{\mathrm{OX} 2}=-4.72 \\
\varepsilon_{\mathrm{HOMO}}=-4.58 \\
\varepsilon_{\text {LUMO }}=-2.27\end{array}$ \\
\hline D6 & $\begin{array}{l}I P_{+}=8.83 \\
I P_{0}=5.68 \\
E A_{0}=0.80\end{array}$ & $\begin{array}{l}\Lambda_{++}=623 \\
\Lambda_{+}=284 \\
\Lambda_{-}=546\end{array}$ & $\begin{array}{l}P_{+}=1.28 \\
P_{0}=1.24 \\
P_{0}=1.24\end{array}$ & $\begin{array}{l}\varepsilon_{\mathrm{OX} 2}=4.68 \\
\varepsilon_{\mathrm{HOMO}}=4.29 \\
\varepsilon_{\text {LUMO }}=2.32\end{array}$ & $\begin{array}{l}\varepsilon_{\mathrm{OX} 2}=-4.71 \\
\varepsilon_{\mathrm{HOMO}}=-4.55 \\
\varepsilon_{\text {LUMO }}=-2.23\end{array}$ \\
\hline D7 & $\begin{array}{l}I P_{+}=8.84 \\
I P_{0}=5.92 \\
E A_{0}=1.24\end{array}$ & $\begin{array}{l}\Lambda_{++}=464 \\
\Lambda_{+}=269 \\
\Lambda_{-}=399\end{array}$ & $\begin{array}{l}P_{+}=1.37 \\
P_{0}=1.35 \\
P_{0}=1.35\end{array}$ & $\begin{array}{l}\varepsilon_{\mathrm{OX} 2}=4.51 \\
\varepsilon_{\mathrm{HOMO}}=4.43 \\
\varepsilon_{\text {LUMO }}=2.78\end{array}$ & $\begin{array}{l}\varepsilon_{\mathrm{OX} 2}=-4.66 \\
\varepsilon_{\mathrm{HOMO}}=-4.57 \\
\varepsilon_{\text {LUMO }}=-2.50\end{array}$ \\
\hline D8 & $\begin{array}{l}I P_{+}=8.54 \\
I P_{0}=5.70 \\
E A_{0}=1.14\end{array}$ & $\begin{array}{l}\Lambda_{++}=462 \\
\Lambda_{+}=356 \\
\Lambda_{-}=367\end{array}$ & $\begin{array}{l}P_{+}=1.30 \\
P_{0}=1.26 \\
P_{0}=1.26\end{array}$ & $\begin{array}{l}\varepsilon_{\mathrm{OX} 2}=4.43 \\
\varepsilon_{\mathrm{HOMO}}=4.26 \\
\varepsilon_{\text {LUMO }}=2.59\end{array}$ & $\begin{array}{l}\varepsilon_{\mathrm{OX} 2}=-4.68 \\
\varepsilon_{\mathrm{HOMO}}=-4.60 \\
\varepsilon_{\text {LUMO }}=-2.48\end{array}$ \\
\hline
\end{tabular}

Table S1. Experimental and simulated CV results under consideration of relaxation and polarization effects. 

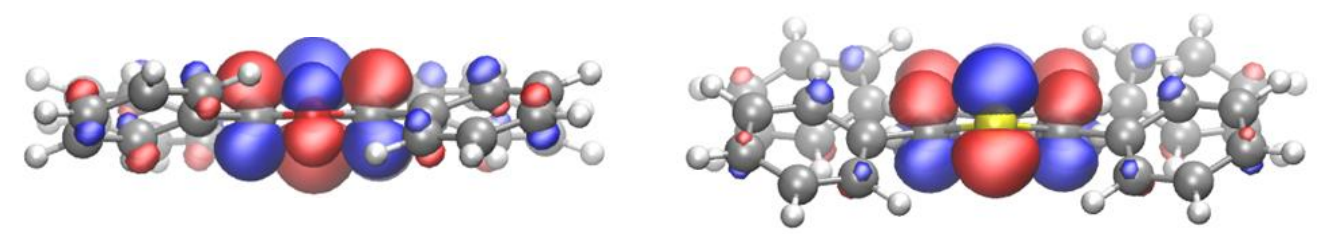

Figure S3 HOMO orbital extension of the donor D1 (oxygen in the backbone) on the left and of the donor D5 (sulfur in the backbone) on the right. The orbital features at the sulfur atoms are more pronounced compared to oxygen atoms leading to reduced features at the side groups. These features at the sulfur atoms have a pronounced extension perpendicular to the molecular plane.

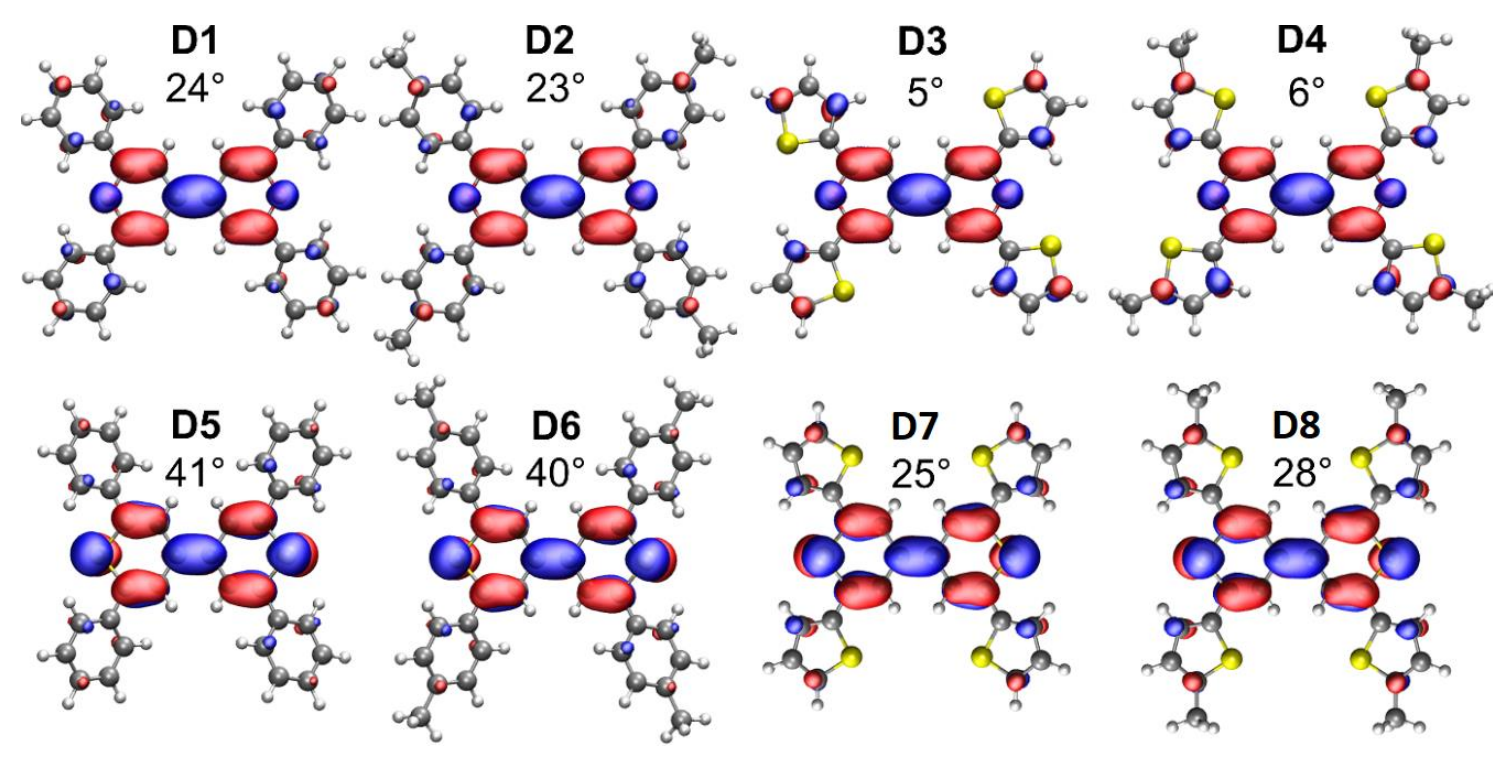

Figure S4. HOMO distribution of the studied donor molecules and "dihedral angles" between the backbone and the side chains (D1 - D4 with oxygen in the backbone; D5 - D8 with sulfur in the backbone). 
Device Architecture

\begin{tabular}{|c|c|c|c|c|c|c|c|c|c|c|c|c|}
\hline Layer & Function & \multicolumn{11}{|c|}{ Thickness [nm] } \\
\hline Glass & Substrate & \multicolumn{11}{|c|}{$10^{6}$} \\
\hline $\mathrm{Ag}$ & Contact / mirror & \multicolumn{11}{|c|}{100} \\
\hline HATNA-F6 & $\begin{array}{l}\text { ETL / hole } \\
\text { blocking }\end{array}$ & \multicolumn{11}{|c|}{6} \\
\hline $\begin{array}{l}\text { BPhen:Cs } \\
(1: 1)\end{array}$ & ETL & 25 & 25 & 25 & 75 & 75 & 75 & 125 & 125 & 125 & 125 & 150 \\
\hline HATNA-F6 & $\begin{array}{l}\text { ETL / hole } \\
\text { blocking }\end{array}$ & \multicolumn{11}{|c|}{6} \\
\hline $\mathrm{C}_{60}$ & ETL & \multicolumn{11}{|c|}{5} \\
\hline $\begin{array}{l}C_{60}: D 8 \\
(5 \text { wt\% D8) }\end{array}$ & $\mathrm{BHJ}$ & 25 & 50 & 75 & 25 & 50 & 75 & 25 & 50 & 75 & 100 & 50 \\
\hline BF-DPB & HTL & \multicolumn{11}{|c|}{12} \\
\hline $\begin{array}{l}\text { BF-DPB:F6- } \\
\text { TCNNQ } \\
\text { (7 wt\% F6- } \\
\text { TCNNQ) }\end{array}$ & HTL & 26 & 26 & 26 & 76 & 76 & 76 & 126 & 126 & 126 & 126 & 176 \\
\hline $\mathrm{MoO}_{3}$ & Seed & \multicolumn{11}{|c|}{3} \\
\hline $\mathrm{Au}$ & Seed & \multicolumn{11}{|c|}{1} \\
\hline $\mathrm{Ag}$ & Contact / mirror & \multicolumn{11}{|c|}{25} \\
\hline $\mathrm{Ag}$ & Protection & \multicolumn{11}{|c|}{75} \\
\hline $\mathrm{MoO}_{3}$ & Protection & \multicolumn{11}{|c|}{10} \\
\hline \multicolumn{13}{|c|}{ Device results } \\
\hline \multicolumn{2}{|c|}{$\begin{array}{l}\text { Full width at half maximum } \\
\text { [nm] }\end{array}$} & 38 & 44 & 47 & 42 & 45 & 50 & 59 & 40 & 53 & 58 & 50 \\
\hline \multicolumn{2}{|c|}{ Resonance peak [nm] } & 605 & 707 & 810 & "908 & 1032 & *1150 & 1244 & 1370 & 1484 & 1581 & ${ }^{*} 1665$ \\
\hline
\end{tabular}

Table S2. Device architecture for cavity-enhanced photodetectors with D8. The device is deposited by thermal evaporation from the bottom layer to the top und illuminated from the bottom. The resonance wavelength is varied from 605 to $1665 \mathrm{~nm}$ by changing the thickness of the layers: BPhen-Cs (1:1), $\mathrm{C}_{60}-\mathrm{D} 8$ and/or BF-DPB: $\mathrm{F}_{6}-$ TCNNQ (7 wt\% $\left.\mathrm{F}_{6}-\mathrm{TCNNQ}\right)$. The materials used are silver (Ag; K. J. Lesker, UK), 2,3,8,9,14,15-hexafluoro-5,6,11,12,17,18-hexatrinaazatrinaphthylene (HATNA-F6; IAPP), 4,7-diphenyl-1,10-phenanthroline (BPhen; Lumtec, Taiwan), caesium (Cs; SAES Getters, Italy), buckminsterfullerene (C60; CreaPhys, Germany), N4,N4'-bis(9,9dimethyl-9H -fluoren-2-yl)-N4,N4'-diphenylbiphenyl-4,4'-diamine (BF-DPB; Synthon), 2,2'- (perfluoronaphthalene-2,6-diylidene)dimalononitrile ( $\mathrm{F}_{6}-\mathrm{TCNNQ;}$ Novaled, Germany), gold (Au; Allgemeine Gold und Silberscheidanstalt, Germany) and molybdenum trioxide ( $\mathrm{MoO}_{3}$; Sigma-Aldrich, USA). (†) Ag layer outside the photoactive area to mechanically stabilize the thin Ag layer. ( $\left.{ }^{*}\right)$ Photodetectors with resonances at $908 \mathrm{~nm}, 1150 \mathrm{~nm}$ and $1665 \mathrm{~nm}$ are investigated regarding their spectral linewidth and noise spectral density as shown in the Figures S8 and S9. 


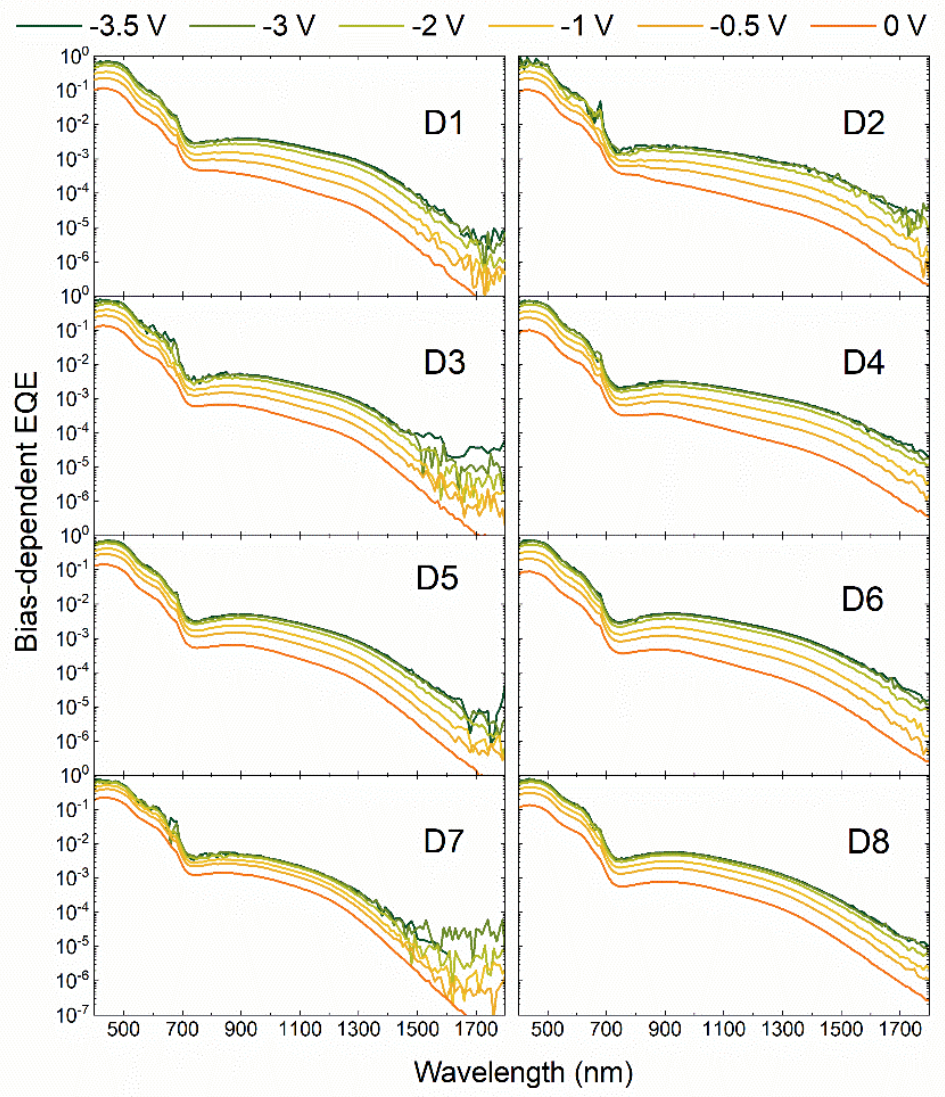

Figure S5. External quantum efficiency of the $\mathrm{D}-\mathrm{C}_{60}$ photodiodes containing the donor materials $\mathrm{D} 1$ to $\mathrm{D} 8$ under reverse bias ranging from 0 to $-3.5 \mathrm{~V}$. Charge collection and charge dissociation efficiencies ( $\eta_{\text {col }}$ and $\eta_{\text {diss }}$ ) improve by increasing the applied absolute voltage bias until photocurrent saturation occurs at $-3.5 \mathrm{~V}$. In that case, the IQE is approximately 1 (IQE $\left.=\eta_{\text {col }} \times \eta_{\text {diss }}\right)$ and therefore the absorption of the active layer can be estimated from the EQE. As the absolute voltage bias increases, voltagedependent shot-noise is increasing as well and can therefore limit sensitivity of the EQE measurement for wavelengths above $1500 \mathrm{~nm}$. 


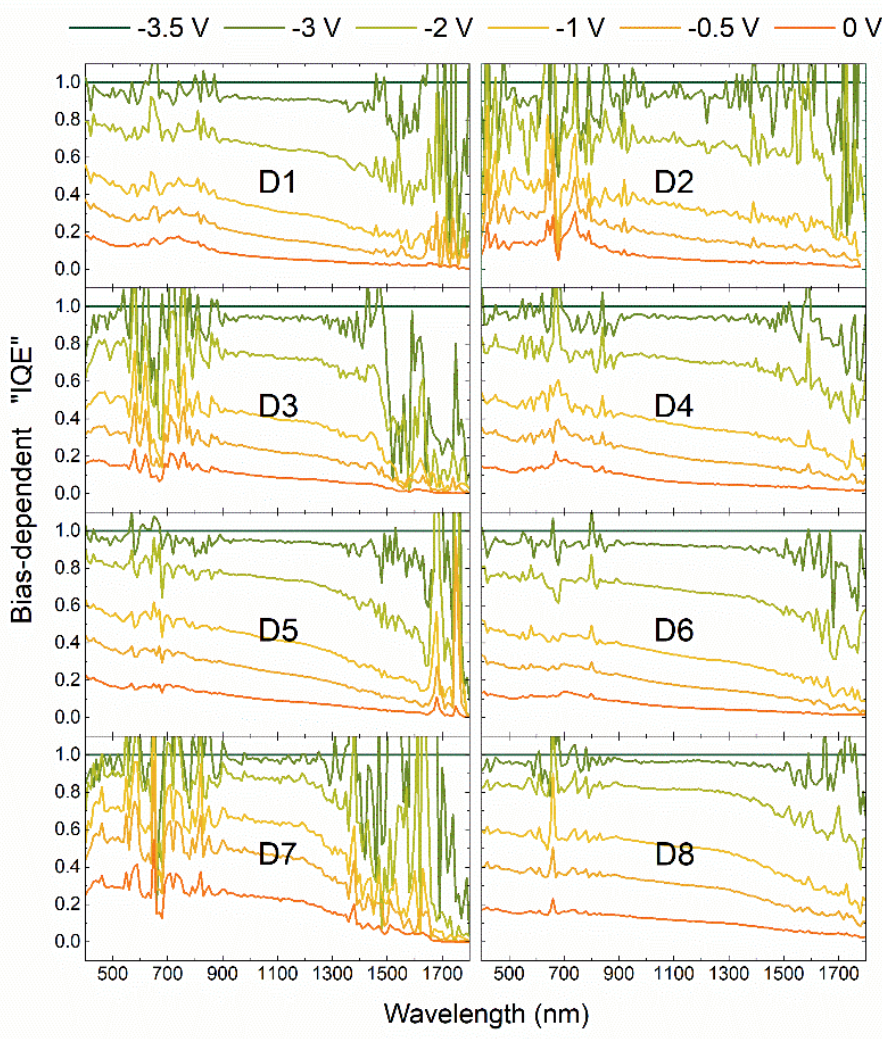

Figure S6. "IQE" of $D-C_{60}$ photodiodes under reverse bias ranging from 0 to $-3.5 \mathrm{~V}$. The IQE is approximated by dividing the EQE by the active layer absorption $(\approx \mathrm{EQE}$ at $-3.5 \mathrm{~V}$ and hence the IQE at $-3.5 \mathrm{~V}$ is 1 ). At $0 \mathrm{~V}$, the average IQE in the VIS spectral range is in close agreement with the simulated IQE using the transfer matrix method. An energy dependence of the IQE is observed as the IQE decreases by maximally one order of magnitude from 400 to $1800 \mathrm{~nm}$. This energy dependence is relatively small compared to 7 orders of magnitude over which the EQE was measured. Measurement limitations, caused by either a low light intensity in the visible spectral range or by the voltage-dependent shot noise, make it impossible to obtain a smooth EQE under applied bias. The EQE noise is translated into strong fluctuations in the "IQE" especially for wavelengths above $1300 \mathrm{~nm}$. 


\section{Internal Quantum Efficiency}

a

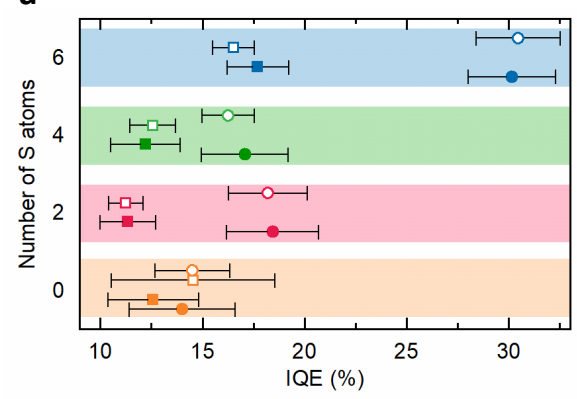

b

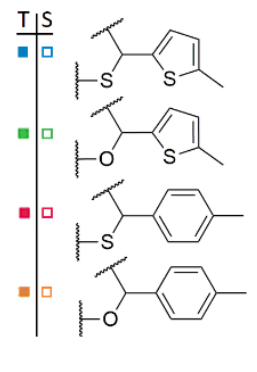

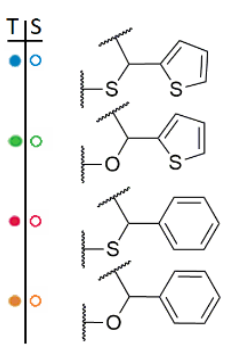

Figure S7. (a) The internal quantum efficiency (IQE) and its standard deviation of photovoltaic diodes using $\mathrm{D}-\mathrm{C}_{60}$ active layers. (b) Characteristic features of the donor molecules used in the active layer blends with $\mathrm{C}_{60}$. Filled and hollow markers represent the IQE obtained by two independent methods (methods $T$ and S). The IQE corresponding to filled markers is determined from the experimental EQE and the simulated absorption of the active layer using the transfer matrix method (method T). The spectral range is limited to $425-525 \mathrm{~nm}$, where the absorption is mainly due to $\mathrm{C}_{60}$ and therefore the unknown optical constants of the donor molecules can be neglected. IQE values corresponding to the hollow markers are obtained from the experimental EQE and by assuming that the saturated EQE under applied bias equals the active layer absorption (method $\mathrm{S}$ ).

\section{Photodetector EQE Linewidth}

a

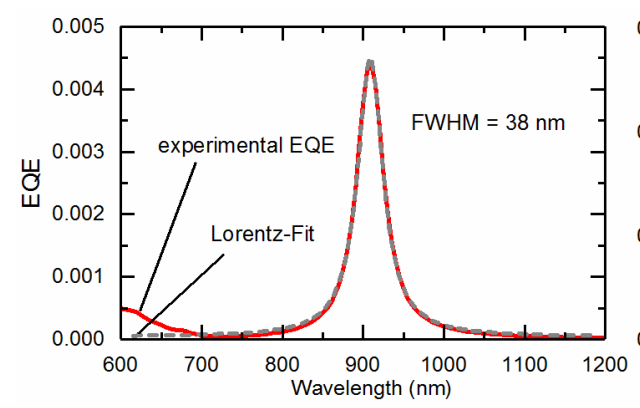

b

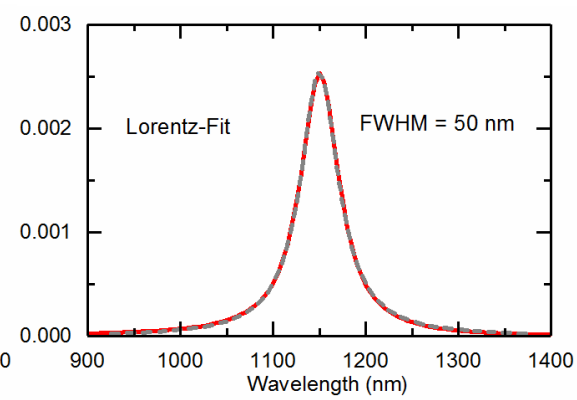

C

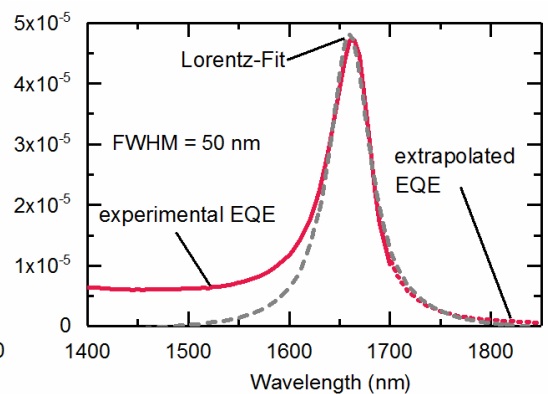

Figure S8. Linewidth (FWHM) of representative photodetectors at (a) $908 \mathrm{~nm}$, (b) $1150 \mathrm{~nm}$ and (c) $1665 \mathrm{~nm}$ determined by a Lorentz-fit to the cavity mode. To fit the EQE of the resonance peak at $1665 \mathrm{~nm}$ beyond $1700 \mathrm{~nm}$ without being limited by the wavelength range of the sensitive EQE measurement, the experimental EQE is extrapolated to wavelengths between 1700 and $1850 \mathrm{~nm}$. 


\section{Noise Characterization}
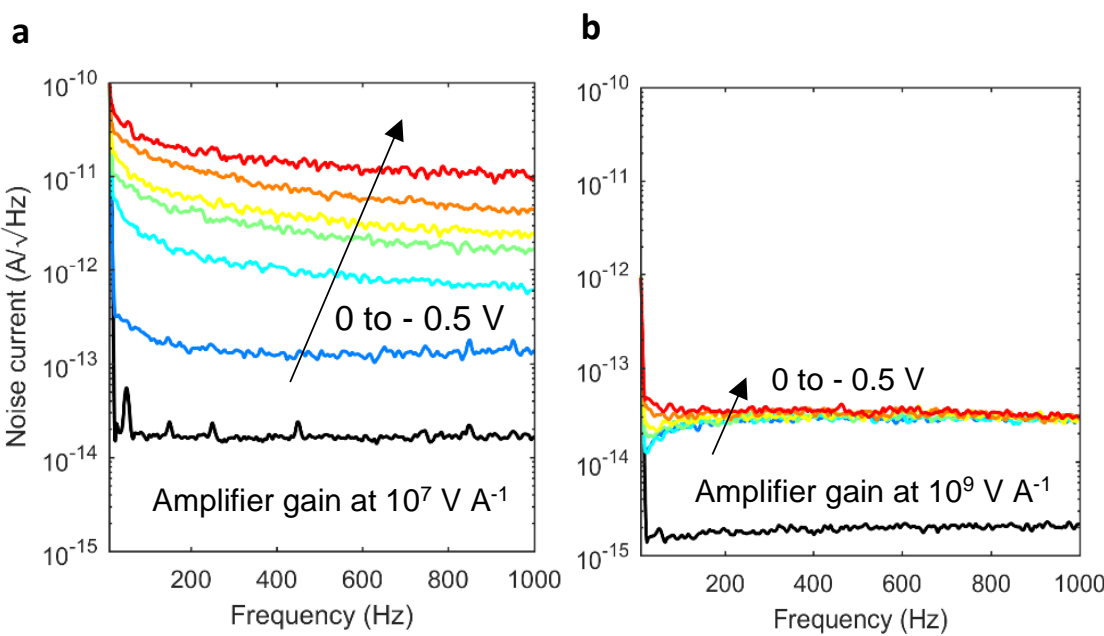

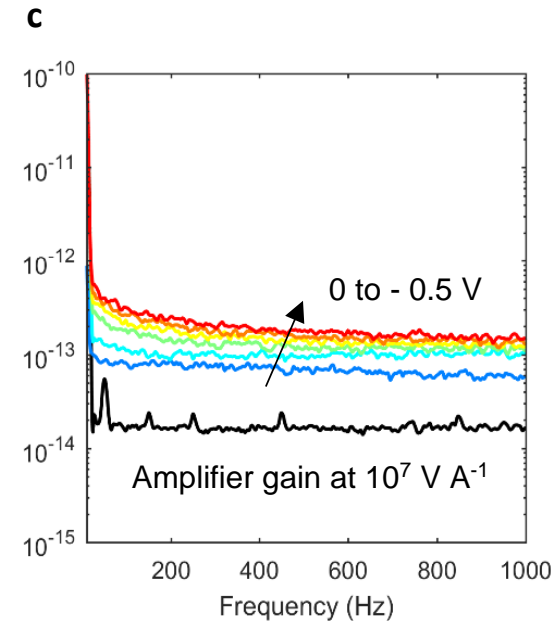

Figure S9. Voltage dependent noise current spectral density of photodetectors with resonances at (a) $908 \mathrm{~nm}$, (b) $1150 \mathrm{~nm}$ and (c) $1665 \mathrm{~nm}$. The black line shows the noise floor of the preamplifier used either at $10^{9} \mathrm{~V} \mathrm{~A}^{-1}$ or $10^{7} \mathrm{~V} \mathrm{~A}^{-1}$ gain. At frequencies below $200 \mathrm{~Hz}$, the photodetector's noise is dominated by the flicker noise and shows a strong dependence on the frequency. As expected, the noise level increases with applied bias, as the shot noise component becomes dominant. We evaluate $D^{*}$ from the noise current at zero bias and $500 \mathrm{mV}$ reverse bias at $1 \mathrm{kHz}$, where the noise current is the least affected by flicker noise, but still within the bandwidth of the preamplifier. We account for the voltage dependence of the EQE by measuring the current response under illumination with a blue laser $(405 \mathrm{~nm})$ at zero applied bias and at $500 \mathrm{mV}$ reverse bias. The ratio of the photocurrent response with and without bias is taken as a factor to estimate the EQE under applied bias from the EQE recorded at zero bias. This procedure assumes that the EQE increases uniformly over the spectrum when voltage is applied, meaning that the rise in the EQE at $405 \mathrm{~nm}$ is the same as in the spectral region of CT absorption. 


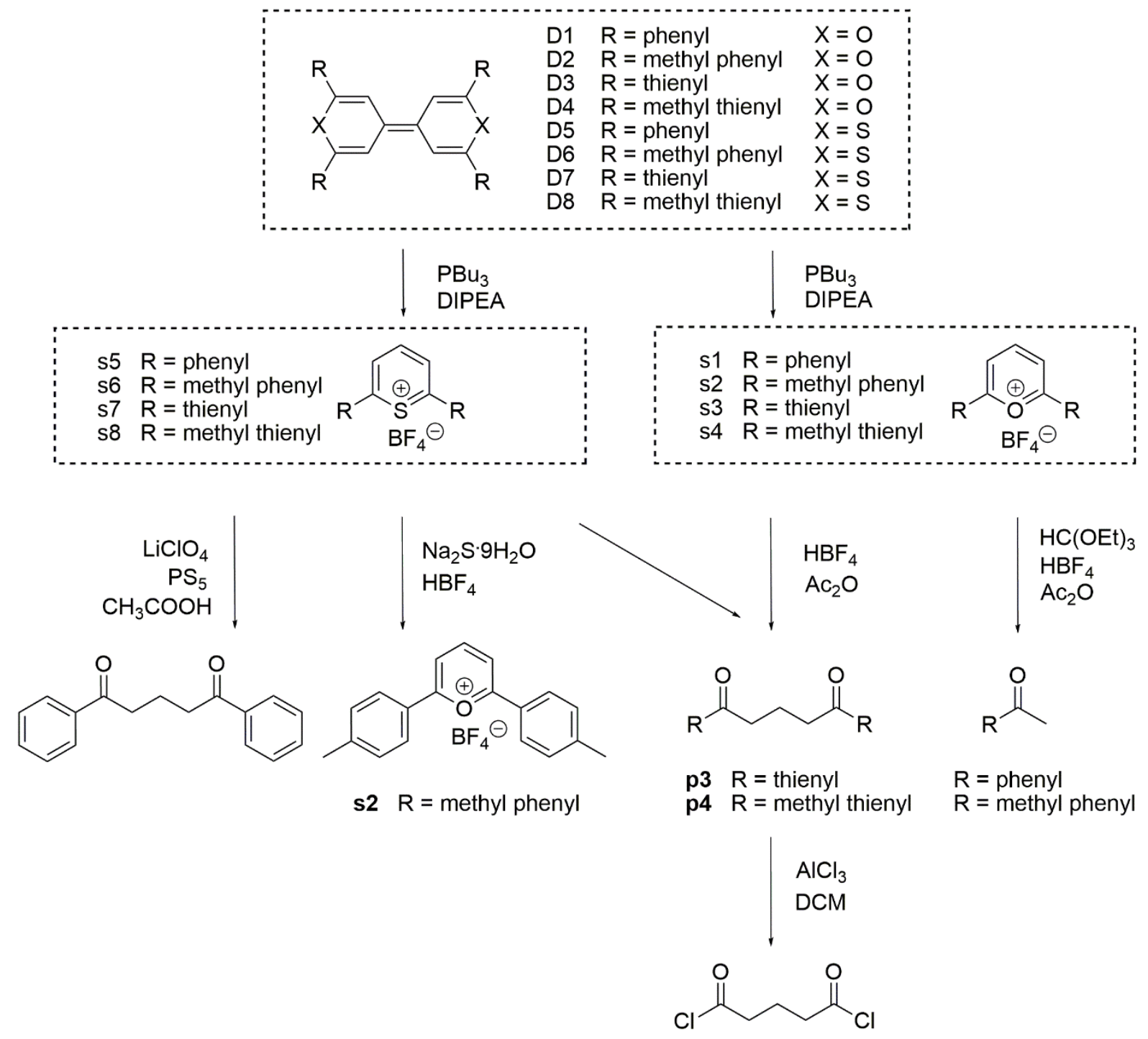

Scheme 1. Retrosynthesis of the donor molecules D1-D8 including the Wittig reaction, the formation of the pyrylium or thiopyrylium salts s1-s8 and the diketones p3-p4 through a Friedel-crafts acylation. The procedure for D1-D8 was adapted from literature [5], as was it for compounds s2-s8 [6] and p3-p4 [7]. To our knowledge the molecules D3, D7 and D8 have not been previously described.

\section{Materials}

All reagents and solvents are purchased from Sigma Aldrich and Acros Organics and used as received. D1 and $\mathbf{s} 1$ are prepared according to procedure previously described.[5]

1,5-Di-(2-thienyl) pentane-1,5-dione (p3) Anhydrous DCM (15 mL) is introduced to $16.0 \mathrm{~g}(0.12 \mathrm{~mol}, 2.4 \mathrm{eq})$ aluminium chloride in a round-bottom flask $(100 \mathrm{~mL})$ under inert atmosphere. A solution of $11.6 \mathrm{~mL}(0.12 \mathrm{~mol}, 2.4 \mathrm{eq})$ thiophene and $6.4 \mathrm{~mL}(0.05$ $\mathrm{mol}, 1 \mathrm{eq}$ ) glutaryl chloride in $15 \mathrm{~mL} \mathrm{DCM}$ is added dropwise via a dropping funnel over 10 min. Upon addition, the colour changes from light orange to dark red. After the mixture was stirred overnight, the flask is cooled in an ice-bath and the reaction is 
quenched with ice and concentrated hydrochloric acid $(2 \mathrm{~mL})$. Under vigorous stirring, water is added until the exothermic reaction of excessive aluminium chloride with water is finished. The mixture is diluted with $50 \mathrm{~mL}$ DCM and left to stir for $2 \mathrm{~h}$. The organic phase is extracted with warm DCM, dried on magnesium sulphate and concentrated under reduced pressure. The crude product is washed with cold diethyl ether (11.2 g, $85 \%) .{ }^{1} \mathrm{H}(500 \mathrm{MHz}$, chloroform) $\delta: 7.73(\mathrm{dd}, \mathrm{J}=3.8,1.1 \mathrm{~Hz}, 1 \mathrm{H}), 7.61$ (dd, J = 4.9, 1.1 Hz, 1H), 7.10 (dd, J = 4.9, 3.8 Hz, 1H), 3.04 (t, J = 7.0 Hz, 2H), 2.19 (qt, $\mathrm{J}=7.0,3.5 \mathrm{~Hz}, 1 \mathrm{H}) \cdot{ }^{13} \mathrm{C}$ NMR $(75 \mathrm{MHz}$, chloroform) $\delta: 193.39,144.81,134.22$, 132.68, 128.78, 38.81, 19.96. ESI-MS: m/z $265[\mathrm{M}]^{+}$.

1,5-Di-(2-(5-methyl)thienyl) pentane-1,5-dione (p4) Anhydrous DCM (15 mL) is introduced to $16.0 \mathrm{~g}(0.12 \mathrm{~mol}, 2.4 \mathrm{eq})$ aluminium chloride in a round-bottom flask $(100 \mathrm{~mL})$ under inert atmosphere. A solution of $11.6 \mathrm{~mL}(0.12 \mathrm{~mol}, 2.4 \mathrm{eq}) 2$-methyl thiophene and $6.4 \mathrm{~mL}(0.05 \mathrm{~mol}, 1.0 \mathrm{eq})$ glutaryl chloride in $15 \mathrm{~mL} \mathrm{DCM}$ is added dropwise via a dropping funnel over 10 min. Upon addition, the colour changes from light orange to dark red. After the mixture was stirred overnight, the flask is cooled in an ice-bath before the reaction is quenched with ice and concentrated hydrochloric acid $(2 \mathrm{~mL})$. Under vigorous stirring, water is added until the exothermic reaction of excessive aluminium chloride with water is finished. The mixture is diluted with $50 \mathrm{~mL}$ DCM and left to stir for $2 \mathrm{~h}$. The organic phase is extracted with warm DCM, dried on magnesium sulphate and concentrated under reduced pressure. The crude product washed with cold diethyl ether $(9.9 \mathrm{~g}, 68 \%) .{ }^{1} \mathrm{H}(500 \mathrm{MHz}$, chloroform $) \delta: 7.53(\mathrm{~d}, \mathrm{~J}=$ $3.7 \mathrm{~Hz}, 1 \mathrm{H}), 6.76(\mathrm{~m}, 1 \mathrm{H}), 2.94(\mathrm{t}, \mathrm{J}=7.0 \mathrm{~Hz}, 2 \mathrm{H}), 2.51(\mathrm{~d}, \mathrm{~J}=0.7 \mathrm{~Hz}, 3 \mathrm{H}), 2.13(\mathrm{p}, \mathrm{J}$ $=7.0 \mathrm{~Hz}, 1 \mathrm{H}) .{ }^{13} \mathrm{C}$ NMR (125.75 MHz, chloroform) $\delta: 192.47,149.60,141.96,132.64$, 126.74, 37.75, 19.72, 15.60. ESI-MS: m/z 293 [M] ${ }^{+}$.

2,6-Di-p-tolylpyrylium tetrafluoroborate (s2) $25.1 \mathrm{~mL} \quad(0.20 \mathrm{~mol}, \quad 1 \mathrm{eq})$ tetrafluoroboric acid solution (50 wt\% in water) is added dropwise over $30 \mathrm{~min}$ to 94.4 $\mathrm{mL}(1.00 \mathrm{~mol}, 5 \mathrm{eq})$ acetic anhydride while keeping the temperature below $15^{\circ} \mathrm{C}$ using an ice salt bath. This solution is added dropwise over $2 \mathrm{~h}$ to $26.8 \mathrm{~g}(0.20 \mathrm{~mol}, 1 \mathrm{eq}) 4^{\prime}-$ methylacetophenone in $100 \mathrm{~mL}(0.60 \mathrm{~mol}, 3 \mathrm{eq})$ triethylorthoformate at room temperature. After the addition is complete, the reaction is left to stir for $2 \mathrm{~h}$ and allowed to stand overnight. The solid formed is collected by vacuum filtration and washed with diethyl ether until the washing decolorized to leave a bright yellow crystalline solid that is left to dry in air $(13.0 \mathrm{~g}, 37 \%) .{ }^{1} \mathrm{H}(500 \mathrm{MHz}$, acetonitrile $) \delta: 8.86(\mathrm{t}, \mathrm{J}=8.3 \mathrm{~Hz}, 1 \mathrm{H})$, $8.40(\mathrm{~d}, \mathrm{~J}=8.3 \mathrm{~Hz}, 2 \mathrm{H}), 8.32-8.20(\mathrm{~m}, 4 \mathrm{H}), 7.60(\mathrm{~d}, \mathrm{~J}=8.2 \mathrm{~Hz}, 4 \mathrm{H}), 2.55(\mathrm{~s}, 6 \mathrm{H})$. ESI-MS: m/z $261\left[\mathrm{M}-\mathrm{BF}_{4}\right]^{+}, 293\left[\mathrm{M}-\mathrm{BF}_{4}+\mathrm{CH}_{3} \mathrm{OH}\right]^{+}$.

2,6-Di-(2-thienyl)pyrylium tetrafluoroborate (s3) $9.7 \mathrm{~mL}(76.2 \mathrm{mmol}, 10 \mathrm{eq})$ tetrafluoroboric acid solution (50 wt\% in water) is added dropwise over $30 \mathrm{~min}$ to a suspension of $2.0 \mathrm{~g}(7.6 \mathrm{mmol}, 1 \mathrm{eq}) \mathrm{p} 3 \mathrm{in} 50 \mathrm{~mL}$ acetic anhydride while keeping the temperature below $15^{\circ} \mathrm{C}$ using an ice salt bath. After the addition is complete, the reaction is left to stir for $2 \mathrm{~h}$ at room temperature and allowed to stand overnight in the refrigerator at $5^{\circ} \mathrm{C}$. A brown solid precipitates upon adding an excessive amount of $500 \mathrm{~mL}$ of hexane/diethyl ether (ratio 1:10). The product is collected by vacuum filtration, washed with diethyl ether and dried in vacuum at room temperature $(1.59 \mathrm{~g}$, $63 \%) .{ }^{1} \mathrm{H}(500 \mathrm{MHz}$, acetonitrile) $\delta: 8.61(\mathrm{t}, \mathrm{J}=8.4 \mathrm{~Hz}, 1 \mathrm{H}), 8.28(\mathrm{dd}, \mathrm{J}=4.0,1.1 \mathrm{~Hz}$, $2 \mathrm{H}), 8.21$ (dd, $\mathrm{J}=4.9,1.1 \mathrm{~Hz}, 2 \mathrm{H}), 8.08(\mathrm{~d}, \mathrm{~J}=8.4 \mathrm{~Hz}, 2 \mathrm{H}), 7.44(\mathrm{dd}, \mathrm{J}=4.9,4.1 \mathrm{~Hz}$, 2H). ${ }^{13} \mathrm{C}$ NMR (75 MHz, acetonitrile) $\delta: 167.00,155.90,140.54,136.98,133.28$, 131.95, 117.71. ESI-MS: m/z $245\left[\mathrm{M}-\mathrm{BF}_{4}\right]^{+}, 277$ [M-BF $\left._{4}+\mathrm{CH}_{3} \mathrm{OH}\right]^{+}$. 
2,6-Di-(2-(5-methyl)thienyl)pyrylium tetrafluoroborate (s4) $9.7 \mathrm{~mL}(76.2 \mathrm{mmol}, 10$ eq) tetrafluoroboric acid solution (50 wt\% in water) is added dropwise over $30 \mathrm{~min}$ to a suspension of $2.2 \mathrm{~g}(7.6 \mathrm{mmol}, 1 \mathrm{eq}) \mathbf{p 4}$ in $50 \mathrm{~mL}$ of acetic anhydride while keeping the temperature below $15^{\circ} \mathrm{C}$ using an ice salt bath. After the addition is complete, the reaction is left to stir for $2 \mathrm{~h}$ at room temperature and allowed to stand overnight in the refrigerator at $5{ }^{\circ} \mathrm{C}$. A red solid precipitated upon adding an excessive amount of $500 \mathrm{~mL}$ of hexane/diethyl ether (ratio 1:10). The product is collected by vacuum filtration, washed with diethyl ether and dried in vacuum at room temperature $(1.0 \mathrm{~g}$, $37 \%) .{ }^{1} \mathrm{H}(500 \mathrm{MHz}$, acetonitrile) $\delta: 8.45$ (t, J = 8.4 Hz, 1H), $8.06(\mathrm{~d}, \mathrm{~J}=4.0 \mathrm{~Hz}, 2 \mathrm{H})$, $7.88(\mathrm{~d}, \mathrm{~J}=8.4 \mathrm{~Hz}, 2 \mathrm{H}), 7.13(\mathrm{dd}, \mathrm{J}=4.0,0.9 \mathrm{~Hz}, 2 \mathrm{H}), 2.66(\mathrm{~s}, 6 \mathrm{H}) .{ }^{13} \mathrm{C} \mathrm{NMR}(75 \mathrm{MHz}$, acetonitrile) $\delta$ : $166.03,157.53,154.45,137.45,131.13,130.83,116.23,16.58$. ESIMS: m/z $273\left[\mathrm{M}-\mathrm{BF}_{4}\right]^{+}, 305\left[\mathrm{M}-\mathrm{BF}_{4}+\mathrm{CH}_{3} \mathrm{OH}\right]^{+}$.

2,6-Diphenylthiopyrylium perchlorate (s5) In a $100 \mathrm{~mL}$ round bottom flask is successively introduced $2.52 \mathrm{~g}$ (10 mmol, $1.0 \mathrm{eq})$ 1,2-diphenylpentane-1,5-dione, 3.34 $\mathrm{g}(15 \mathrm{mmol}, 1.5 \mathrm{eq})$ phosphorous pentasulfide, $60 \mathrm{~mL}$ acetic acid and $6.40 \mathrm{~g}(60 \mathrm{mmol}$, 6.0 eq) lithium perchlorate. The mixture is heated under reflux for $3 \mathrm{~h}$ and the colour changes from yellow to orange. A white solid is filtered and washed with hot acetic acid. The filtrate is reduced in pressure and the product is precipitated by adding 50 $\mathrm{mL}$ of diethyl ether. After storing the mixture in the refrigerator at $5{ }^{\circ} \mathrm{C}$ overnight, a yellow solid is collected, washed with diethyl ether and dried in air $(3.26 \mathrm{~g}, 94 \%) .{ }^{1} \mathrm{H}$ $(500 \mathrm{MHz}$, acetonitrile) $\delta: 8.94(\mathrm{dd}, \mathrm{J}=9.6,7.8 \mathrm{~Hz}, 1 \mathrm{H}), 8.85(\mathrm{~m}, 2 \mathrm{H}), 8.04(\mathrm{dd}, \mathrm{J}=$ 5.3, 3.2 Hz, 4H), 7.83 (ddd, $\mathrm{J}=6.8,3.9,1.2 \mathrm{~Hz}, 2 \mathrm{H}), 7.75(\mathrm{~m}, 4 \mathrm{H}) .{ }^{13} \mathrm{C}$ NMR (125.75 MHz, acetonitrile) $\delta: 172.41,151.72,135.51,135.06,133.98,131.87,130.02$. ESI-MS: m/z $249\left[\mathrm{M}-\mathrm{ClO}_{4}\right]^{+}$.

2,6-Di-p-tolylpyrylium tetrafluoroborate (s6) A clear solution of $5.0 \mathrm{~g}(14.4 \mathrm{mmol}$, $1.00 \mathrm{eq}) \mathbf{s} 2$ in acetone $(250 \mathrm{~mL})$ is warmed up to $40^{\circ} \mathrm{C}$ and a solution of $6.9 \mathrm{~g}(28.7$ mmol, 2.00 eq) $\mathrm{Na}_{2} \mathrm{~S} \cdot 9 \mathrm{H}_{2} \mathrm{O}$ in water $(70 \mathrm{~mL})$ is added. The ruby-red suspension is stirred for $2 \mathrm{~h}$ and an aqueous solution of $60 \mathrm{~mL} \mathrm{HBF}_{4}(50 \mathrm{wt} \%$ in water) $(0.5 \mathrm{mmol}$, $0.03 \mathrm{eq})$ is added, followed by an addition of water $(200 \mathrm{~mL})$. A three phase system comprising a red suspension and a viscous dark red oil is obtained and left to stir vigorously for $30 \mathrm{~min}$. After leaving the mixture to stand for further $30 \mathrm{~min}$, the dark red oil has collected at the stirring bar and can be removed easily. The suspension is reduced in pressure at no more than $40^{\circ} \mathrm{C}$ to give a precipitate in a clear solution. After storing the mixture in the refrigerator at $5{ }^{\circ} \mathrm{C}$ overnight, an orange solid is collected, washed with diethyl ether and dried in air $(3.24 \mathrm{~g}, 62 \%)$. ${ }^{1} \mathrm{H} \mathrm{NMR}(500 \mathrm{MHz}$, acetonitrile) $\delta: 8.83$ (t, J = 8.3 Hz, 1H), $8.38(\mathrm{~d}, \mathrm{~J}=8.3 \mathrm{~Hz}, 2 \mathrm{H}), 8.23(\mathrm{~d}, \mathrm{~J}=8.4 \mathrm{~Hz}$, $4 \mathrm{H}), 7.57(\mathrm{~m}, 4 \mathrm{H}), 2.52(\mathrm{~s}, 6 \mathrm{H}) .{ }^{13} \mathrm{C} \mathrm{NMR}(125.75 \mathrm{MHz}$, acetonitrile) $\delta: 171.48,150.93$, 146.98, 132.47, 132.15, 132.01, 129.42, 21.68. ESI-MS: m/z 277 [M-BF $]^{+}$.

2,6-Dithienylthiopyrylium perchlorate (s7) In a $250 \mathrm{~mL}$ round bottom flask is successively introduced $7.80 \mathrm{~g}(29.5 \mathrm{mmol}, 1.0 \mathrm{eq}) \mathrm{p3}, 9.86 \mathrm{~g}(44.3 \mathrm{mmol}, 1.5 \mathrm{eq})$ phosphorous pentasulfide, $180 \mathrm{~mL}$ acetic acid and $18.90 \mathrm{~g}(60 \mathrm{mmol}, 6.0 \mathrm{eq})$ lithium perchlorate. The mixture is heated under reflux for $3 \mathrm{~h}$ and the colour changes from orange to deep red. A dark green solid is filtered using a hot filter and washed thoroughly with hot acetic acid. The filtrate is reduced in pressure and a black solid is precipitated by adding an excessive amount of diethyl ether and leaving the mixture in the refrigerator at $5{ }^{\circ} \mathrm{C}$ overnight. The crude product is collected and recrystallized in 
acetic acid to yield dark green crystals $(3.0 \mathrm{~g}, 28 \%) .{ }^{1} \mathrm{H}(500 \mathrm{MHz}$, acetonitrile) $\delta: 8.55$ $(\mathrm{t}, \mathrm{J}=8.8 \mathrm{~Hz}, 1 \mathrm{H}), 8.43(\mathrm{~d}, \mathrm{~J}=8.7 \mathrm{~Hz}, 2 \mathrm{H}), 8.20-8.04(\mathrm{~m}, 4 \mathrm{H}), 7.42(\mathrm{dd}, \mathrm{J}=4.9,4.0$ $\mathrm{Hz}, 2 \mathrm{H}) .{ }^{13} \mathrm{C}$ NMR $(125.75 \mathrm{MHz}$, acetonitrile) $\delta: 162.24,151.35,139.07,137.80$, 134.81, 132.50, 130.26. ESI-MS: m/z $261\left[\mathrm{M}-\mathrm{ClO}_{4}\right]^{+}$.

2,6-Di-(5-ethylthienyl)thiopyrylium perchlorate (s8) In a $250 \mathrm{~mL}$ round bottom flask is successively introduced $5.00 \mathrm{~g}(17.1 \mathrm{mmol}, 1.0 \mathrm{eq}) \mathrm{p} 4,5.72 \mathrm{~g}(25.7 \mathrm{mmol}, 1.5 \mathrm{eq})$ phosphorous pentasulfide, $250 \mathrm{~mL}$ acetic acid and $10.90 \mathrm{~g}$ (102.2 mmol, $6.0 \mathrm{eq})$ lithium perchlorate. The mixture is heated under reflux for $3 \mathrm{~h}$ and the color changes from orange to deep violet. The solution is filtered using hot filter and feeding bottle, and left to stand for $48 \mathrm{~h}$. Dark green crystals are collected, washed with diethyl ether and dried in air $(2.16 \mathrm{~g}, 33 \%) .{ }^{1} \mathrm{H}(300 \mathrm{MHz}$, acetonitrile) $\delta: 8.38(\mathrm{dd}, \mathrm{J}=9.5,8.1 \mathrm{~Hz}$, $1 \mathrm{H}), 8.25-8.15(\mathrm{~m}, 2 \mathrm{H}), 7.93(\mathrm{~d}, \mathrm{~J}=4.0 \mathrm{~Hz}, 2 \mathrm{H}), 7.13(\mathrm{dd}, \mathrm{J}=4.0,1.0 \mathrm{~Hz}, 2 \mathrm{H}), 2.65$ (s, $6 \mathrm{H}) .{ }^{13} \mathrm{C}$ NMR $(75 \mathrm{MHz}$, acetonitrile) $\delta: 161.09,156.02,150.44,135.56,135.27$, 131.57, 128.49, 16.76. ESI-MS: m/z 289 [M-ClO4] ${ }^{+}$.

2,2',6,6'-tetra-p-tolyl-4,4'-bipyranylidene (D2) In a glovebox s2 (4 g, $12.5 \mathrm{mmol})$ is suspended in $40 \mathrm{ml}$ of dry acetonitrile. Upon addition of $\mathrm{n}$-tributylphosphine ( $\left.\mathrm{PBu}_{3}\right)$ (3.2 $\mathrm{ml}, 12.5 \mathrm{mmol}$ ) the suspension turns orange and is left to stir for $2 \mathrm{~h}$ at room temperature. DIPEA $(8.4 \mathrm{ml}, 63 \mathrm{mmol})$ is added to yield a deep red solution. The reaction mixture is removed from the glovebox and placed in an oil bath at $90^{\circ} \mathrm{C}$ under nitrogen, heated to reflux for a further $2 \mathrm{~h}$ and left to cool to room temperature overnight. The precipitate formed is filtered and washed with $20 \mathrm{ml}$ of acetonitrile and $20 \mathrm{ml}$ of diethyl ether to leave a dark red solid that is dried in air $(0.72 \mathrm{~g}, 45 \%) .{ }^{1} \mathrm{H}$

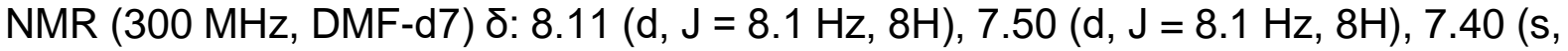
4H), 2.57 (s, 12H). ESI-MS: m/z: $548.6[\mathrm{M}+28]^{+}$.

2,2',6,6'-tetrathienyl-4,4'-bipyranylidene (D3) Under inert atmosphere, $1.2 \mathrm{~mL}$ (4.7 $\mathrm{mmol}, 1 \mathrm{eq}) \mathrm{PBu}_{3}$ is added to an orange suspension of $1.56 \mathrm{~g}(4.7 \mathrm{mmol}, 1 \mathrm{eq}) \mathrm{s} 3 \mathrm{in}$ $50 \mathrm{~mL}$ dry acetonitrile. The mixture changes colour to yellow and is stirred for $2.5 \mathrm{~h}$ at ambient temperature, followed by an addition of $4.0 \mathrm{~mL}(23.5 \mathrm{mmol}, 5 \mathrm{eq})$ DIPEA. The mixture is refluxed at $95^{\circ} \mathrm{C}$ for $2 \mathrm{~h}$ in inert atmosphere and then left to stand overnight. A black solid is collected by filtration, washed with acetonitrile and dried in air $(0.62 \mathrm{~g}$, $54 \%$ \%). ${ }^{1} \mathrm{H}(500 \mathrm{MHz}, \mathrm{DMSO}) \delta: 7.74(\mathrm{dd}, \mathrm{J}=3.7,1.1 \mathrm{~Hz}, 1 \mathrm{H}), 7.65(\mathrm{dd}, \mathrm{J}=5.0,1.1$ $\mathrm{Hz}, 1 \mathrm{H}), 7.21(\mathrm{dd}, \mathrm{J}=5.0,3.7 \mathrm{~Hz}, 1 \mathrm{H}), 6.95(\mathrm{~s}, 1 \mathrm{H}) .{ }^{13} \mathrm{C}$ NMR $(125.75 \mathrm{MHz}, \mathrm{DMSO})$ $[\mathrm{ppm}]=144.90,136.50,12.08,126.42,124.15,113.68,101.85 . \mathrm{ES}-\mathrm{MS}: \mathrm{m} / \mathrm{z}: 488$ [M] ${ }^{+}$.

2,2',6,6'-tetra-(2-methylthienyl)-4,4'-bipyranylidene (D4) Under inert atmosphere, $1.2 \mathrm{~mL}(4.7 \mathrm{mmol}, 1 \mathrm{eq}) \mathrm{PBu}_{3}$ is added to the orange suspension of $1.69 \mathrm{~g}(4.7 \mathrm{mmol}$, $1 \mathrm{eq}) \mathbf{s} 4$ in $50 \mathrm{~mL}$ dry acetonitrile. The mixture changes colour to yellow and is stirred for $2.5 \mathrm{~h}$ at ambient temperature, followed by an addition of $4.0 \mathrm{~mL}(23.7 \mathrm{mmol}, 5 \mathrm{eq})$ DIPEA. The mixture is refluxed at $95^{\circ} \mathrm{C}$ for $2 \mathrm{~h}$ in inert atmosphere and then left to stand overnight. A black solid is collected by filtration, washed with acetonitrile and dried in air $(0.89 \mathrm{~g}, 70 \%) .{ }^{1} \mathrm{H}(600 \mathrm{MHz}$, benzene $) \delta: 7.16(\mathrm{~s}, 1 \mathrm{H}), 6.45(\mathrm{~d}, \mathrm{~J}=3.0 \mathrm{~Hz}$, 1H), 6.40 (br.s, 1H), 2.11 (br.s, 3H). HR-El-MS: m/z 544.0661 [M] .

2,2',6,6'-tetraphenyl-4,4'-bithiopyranylidene (D5) In a glove box, $2.2 \mathrm{~mL}$ (9 mmol, $1 \mathrm{eq}) \mathrm{PBu}_{3}$ is added to a brown suspension of $\left.3.0 \mathrm{~g} \mathrm{(9} \mathrm{mmol,} 1 \mathrm{eq}\right) \mathrm{s} 5$ in $60 \mathrm{~mL}$ dry acetonitrile. The suspension changes colour to yellow and is stirred for $2.5 \mathrm{~h}$ at ambient temperature, followed by an addition of $7.8 \mathrm{~mL}$ ( $45 \mathrm{mmol}, 5 \mathrm{eq})$ DIPEA. The mixture 
is refluxed at $95^{\circ} \mathrm{C}$ for $2 \mathrm{~h}$ in inert atmosphere and then left to stand overnight. Black crystals are collected by filtration, washed with cold acetonitrile and dried in air $(0.74$ g, 33 \%). EA calculated for $\mathrm{C}_{34} \mathrm{H}_{24} \mathrm{~S}_{2}$ : C, 82.22; $\mathrm{H}, 4.87 ; \mathrm{S}, 12.91$ found: $\mathrm{C}, 82.89 ; \mathrm{H}$, 4.95; S, 12.43. HR-EI-MS: m/z 496.1324 [M]'.

2,2',6,6'-tetra-p-tolyl-4,4'-bithiopyranylidene (D6) In a glove box, $2.2 \mathrm{~mL}(9 \mathrm{mmol}$, 1 eq) $\mathrm{PBu}_{3}$ is added to a brown suspension of $\left.3.28 \mathrm{~g} \mathrm{(9} \mathrm{mmol,} 1 \mathrm{eq}\right) \mathrm{s} 6$ in $60 \mathrm{~mL}$ dry acetonitrile. The suspension changes colour to yellow and is stirred for $2.5 \mathrm{~h}$ at ambient temperature, followed by an addition of $7.8 \mathrm{~mL}(45 \mathrm{mmol}, 5 \mathrm{eq})$ DIPEA. The mixture is refluxed at $95^{\circ} \mathrm{C}$ for $2 \mathrm{~h}$ in inert atmosphere and then left to stand overnight. Dark green crystals are collected by filtration, washed with cold acetonitrile and dried in air $\left(0.88 \mathrm{~g}, 36 \%\right.$ \%). EA calculated for $\mathrm{C}_{38} \mathrm{H}_{32} \mathrm{~S}_{2}$ : C, 82.57; H, 5.84; S, 11.60 found: C, 82.77; H, 5.78; S, 11.42. HR-EI-MS: m/z 552.1948 [M] ${ }^{+}$.

2,2',6,6'-tetrathienyl-4,4'-bithiopyranylidene (D7) Under inert atmosphere, $0.65 \mathrm{~mL}$ (2.6 mmol, 1 eq) $\mathrm{PBu}_{3}$ is added to a violet suspension of $0.95 \mathrm{~g}(2.6 \mathrm{mmol}, 1 \mathrm{eq}) \mathrm{CK} 65$ in $50 \mathrm{~mL}$ dry acetonitrile. The mixture changes colour to grey and is stirred for $2.5 \mathrm{~h}$ at ambient temperature, followed by an addition of $2.2 \mathrm{~mL}(13.0 \mathrm{mmol}, 5 \mathrm{eq})$ DIPEA. The mixture is refluxed at $95^{\circ} \mathrm{C}$ for $2 \mathrm{~h}$ in inert atmosphere and then left to stand overnight. Black crystals are collected by filtration and recrystallized from DMSO $(0.26 \mathrm{~g}, 39 \%)$. ${ }^{1} \mathrm{H}$ NMR $(500 \mathrm{MHz}$, pyridine) $\delta: 7.52(\mathrm{dd}, \mathrm{J}=5.1,1.1 \mathrm{~Hz}, 1 \mathrm{H}), 7.50-7.46(\mathrm{~m}, 1 \mathrm{H})$, $7.40(\mathrm{~s}, 1 \mathrm{H}), 7.13$ (dd, J = 5.1, 3.7 Hz, 1H). ESI-MS: m/z $520[\mathrm{M}]^{+}$.

2,2',6,6'-tetra-(2-methylthienyl)-4,4'-bithiopyranylidene (D8) Under inert atmosphere, $0.7 \mathrm{~mL}(2.8 \mathrm{mmol}, 1 \mathrm{eq}) \mathrm{PBu}_{3}$ is added to a violet suspension of $1.10 \mathrm{~g}$ (2.8 mmol, $1 \mathrm{eq}$ ) $\mathbf{s} 8$ in $50 \mathrm{~mL}$ dry acetonitrile. The mixture changes colour to grey and is stirred for $2.5 \mathrm{~h}$ at ambient temperature, followed by an addition of $2.4 \mathrm{~mL}$ $(14.0 \mathrm{mmol}, 5 \mathrm{eq})$ DIPEA. The mixture is refluxed at $95^{\circ} \mathrm{C}$ for $2 \mathrm{~h}$ in inert atmosphere and then left to stand overnight. Black crystals are collected by filtration and recrystallized from DMSO (0.58 g, $72 \%)$. ${ }^{1} \mathrm{H}$ NMR (500 MHz, pyridine) $\delta: 7.35$ (m, $1 \mathrm{H}), 7.29(\mathrm{~d}, \mathrm{~J}=3.6 \mathrm{~Hz}, 1 \mathrm{H}), 6.76(\mathrm{dd}, \mathrm{J}=3.6,1.1 \mathrm{~Hz}, 1 \mathrm{H}), 2.33(\mathrm{~s}, 3 \mathrm{H})$. ESI-MS: $\mathrm{m} / \mathrm{z}$ $576[\mathrm{M}]^{+}$.

\section{$\underline{\text { References }}$}

[1] V. Coropceanu, A. Demetrio, S. Filho, Y. Olivier, R. Silbey, and J. Bre, "Charge Transport in Organic Semiconductors," Chem. Rev., vol. 107, pp. 926-952, 2007.

[2] A. Weller, "Photoinduced Electron Transfer in Solution: Exciplex and Radical Ion Pair Formation Free Enthalpies and their Solvent Dependence," Zeitschrift für Phys. Chemie, vol. 133, no. 1, pp. 93-98, 1982.

[3] R. Scholz et al., "Quantifying charge transfer energies at donor-acceptor interfaces in small-molecule solar cells with constrained DFTB and spectroscopic methods," J. Phys. Condens. Matter, vol. 25, no. 47, p. 473201, 2013.

[4] X. Wang et al., "Synthesis of NBN-Type Zigzag-Edged Polycyclic Aromatic Hydrocarbons: 1,9-Diaza-9a-boraphenalene as a Structural Motif," J. Am. 
Chem. Soc., vol. 138, no. 36, pp. 11606-11615, 2016.

[5] A. Bolag, J.-I. Nishida, K. Hara, and Y. Yamashita, "Enhanced performance of dye-sensitized solar cells with novel 2,6-diphenyl-4H-pyranylidene dyes," Org. Electron., vol. 13, pp. 425-431, 2012.

[6] G. A. Reynolds and C. H. Chen, "Synthesis of Certain Bipyranylidene and Bi(thiopyranylidene) Derivates," J. Org. Chem., vol. 44, pp. 4456-4458, 1979.

[7] S. Berny, L. Tortech, M. Véber, and D. Fichou, "Dithiapyrannylidenes as efficient hole collection interfacial layers in organic solar cells," ACS Appl. Mater. Interfaces, vol. 2, no. 11, pp. 3059-3068, 2010. 